\title{
Copper-diimine coordination compounds as potential new tools in the treatment of cancer
}

\author{
Natalia Alvarez ${ }^{1}$, M Gabriela Kramer ${ }^{2}$, Javier Ellena ${ }^{3}$, Antonio Costa-Filho ${ }^{4}$, María H Torre ${ }^{1}$ and Gianella Facchin $^{1 *}$ \\ ${ }^{1}$ Facultad de Química, General Flores 2124, Universidad de la República, Montevideo, Uruguay \\ ${ }^{2}$ Laboratory of Carbohydrates and Glycoconjugates, Facultad de Química, Universidad de la República, Uruguay \\ ${ }^{3}$ Instituto de Física de São Carlos, Universidade de São Paulo, C.P. 369, 13560-970, São Carlos (SP), Brazil \\ ${ }^{4}$ Faculdade de Filosofia, Ciências e Letras de Ribeirão Preto, Universidade de São Paulo, Av. Bandeirantes, 14040-901, Ribeirão Preto (SP), Brazil
}

\begin{abstract}
The usefulness of coordination metal compounds in cancer chemotherapy was firstly demonstrated by Cisplatin. As a result of an intense research on the field of copper complexes with antitumor activity, copper coordination compounds are emerging as an alternative for the development of drugs for the treatment cancer. Our research is devoted to find new metal containing drugs for the treatment of cancer. This paper summarizes our results on the study of Copper-diimine of ternary complexes and related Copper homoleptic complexes as cytotoxic agents. The studied diimines were 2,2-dipyridil-amine, bypiridine, $4,4^{\prime}-2,2$ bipyridine, 1,10 phenanthroline, 4-methyl-1,10 phenanthroline, 5- $\mathrm{NO}_{2}$-phenanthroline, neocuproine and bathophenanthroline. L-dipeptides, iminodiacetic acid or phosphines were used as coligands. Most of the complexes present higer cytotoxicity than Cisplatin. We hypothesize that the cation $[\mathrm{Cu}(\text { diimine })]^{2+}$ is the active species of the complexes.
\end{abstract}

\section{Introduction}

The usefulness of coordination metal compounds in cancer chemotherapy was firstly demonstrated by Cisplatin, cisdiamminedichloridoplatinum(II) [1]. While the anticancer activity of this drug was somewhat serendipitously discovered in the '60s still is a widely used chemotherapeutic drug to treat cancers. Its clinical applications are limited by its side effects and drug resistance. The discovery of the activity of Cisplatin started an extensive research on Pt compounds that yielded several other compounds with antitumor activity, some of them in clinical use as Carboplatin and Oxaliplatin [2-4].

Complexes of other metals than Pt started to be studied, many with promising results. Different metal complexes may present different mechanism of action than Cisplatin and congeners and therefore different spectra of activity [3-6].

In this search for complexes with antitumor activity one strategy was to study coordination compounds of essential metals. This research was initially performed considering that living organisms already have metabolic pathways for these metals, and therefore may present less severe side effects. Different $\mathrm{Cu}(\mathrm{II})$ and $\mathrm{Cu}(\mathrm{I})$ complexes with antitumor activity have been synthesized and characterized as reviewed [7-9], some with encouraging results. Many $\mathrm{Cu}$ (II) complexes are active in spite of its ligands not having appreciable cytotoxic activity. As a result, copper coordination compounds are emerging as an alternative for the development of drugs for the treatment of cancer.

To the date, two copper compounds are about to start clinical trials. Casiopeina III-ia $\left[(\mathrm{Cu}(\mathrm{II}))\left(4,4^{\prime}\right.\right.$-dimethyl-2,2'-bipyridine) (acetylacetonate) $\left.\left(\mathrm{NO}_{3}\right)\left(\mathrm{H}_{2} \mathrm{O}\right)\right]$, developed by L. Ruiz and co-workers has completed the preclinical trials required to start clinical phase I studies in Mexico [10,11]. HydroCuP the phosphino copper(I) complex $\left[\mathrm{Cu}\right.$ (tris-hydroxymethylphosphine) $\left.{ }_{4}\right]\left[\mathrm{PF}_{6}\right]$, presents highly selective antitumor effects, showing promising results in latter preclinical studies $[12,13]$.
The mechanism of action of copper compounds is not completely understood and possibly includes different molecular events $[7,14,15]$. Copper presents two oxidation states $+\mathrm{I}$ and $+\mathrm{II}$ which gives rise to a rich redox chemistry that may lead to the production of reactive oxygen species (ROS). ROS production is considered to be a relatively selective mechanism, as cancer cells are more vulnerable to oxidative stress than normal cells [16]. There are studies that relate cytotoxic activity with an increased intracellular copper uptake induced by the complexes $[17,18]$. According to those observations, $\mathrm{Cu}(\mathrm{I} / \mathrm{II})$ would be the final active species, being the complex a "carrier" of $\mathrm{Cu}$ to the cell. The proposed mechanism of action of Casiopeinas includes DNA binding. ROS production and oxidative damage of relevant biomolecules, leading to apoptosis of the cells $[11,19]$. HydroCuP induces parapototic cell death due to endoplasmatic reticulum stress [13].

In relation to the diiminc ligands, 1,10-phenanthroline (phen) is one of the more common ligands used in coordination chemistry as it forms stable complexes with several metallic cations. Homoleptic $\mathrm{Cu}$-complexes, $\left[\mathrm{Cu}(\text { phen })_{2}\right]^{+}$and $\left[\mathrm{Cu}(\text { phen })_{2}\right]^{2+}$ bind to the minor groove of the double stranded DNA noncovalently, cleaving DNA at its binding region [20-23]. In addition, a number of heteroleptic phen-containing $\mathrm{Cu}$ (II) complexes show DNA binding and nuclease activity. Many of them present cytotoxic activity on tumor cell lines $[24,25]$. The 5- $\mathrm{NO}_{2}-1,10$-phenanthroline $\left(5-\mathrm{NO}_{2}\right.$-phen) ligand presents different hydrophobicity and hydrogen bonding properties than the 1,10-phenanthroline (phen). It acts as an electron-attractor substituent, modifying the electronic properties of the molecule. These properties may influence their complexes reactivity, possibly showing

*Correspondence to: Gianella Facchin, Facultad de Química, General Flores 2124, Universidad de la República, Montevideo, Uruguay, E-mail: gfacchin@ fq.edu.uy

Received: July 17, 2018; Accepted: July 27, 2018; Published: July 31, 2018 
different ability to bind to DNA than Cu-phen complexes [20-23]. As a result, their cytotoxic activity may be different. This difference possibly extends to heteroleptic $5-\mathrm{NO}_{2}$-phen complexes.

Our research is devoted to find new metal containing compounds which may be useful for the treatment of cancer. In this paper we summarize our results on the study of Copper-diimine heteroleptic complexes and related Copper homoleptic complexes as cytotoxic agents. Figure 1 presents the diiminic ligands studied in this work. As anionic ligands, in order to form neutral complexes, L-dipeptide, diiminodiacetate (ida) were used. For the $\mathrm{Cu}(\mathrm{I})$ complexes phosphines were used as coligands.

\section{Cytotoxic activity of Copper complexes containing diimines}

Table 1 [28-30] summarizes the results we have already obtained for different studied $\mathrm{Cu}$-diimine containing complexes. Most of them present increased cytotoxic activity when compared to Cisplatin. Results are analyzed according to compound chemical groups.

\section{Homoleptic CuL-dipeptide and $\mathrm{Cu}$-diimine complexes}

We started our studies on cytotoxic copper compounds preparing $\mathrm{Cu}$-L-dipeptide complexes.

In relation to their possible mechanism of action, we studied their binding to (isolated) Calf Thymus DNA. EPR studies showed that the

Table 1. Cytotoxic activity expressed by $\mathrm{IC}_{50}$ (unless specified) of the studied complexes against MDA-MB-23 (human metastatic breast cancer), MCF-7 (human metastatic breast adenocarcinoma) HeLa (human cervical adenocarcinoma), and A549 (human lung epithelial carcinoma) cell lines

\begin{tabular}{|c|c|c|c|c|c|}
\hline Compound & 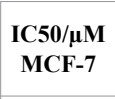 & 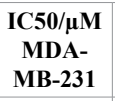 & 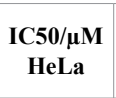 & 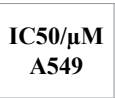 & Ref. \\
\hline $\mathrm{Cu}$ (L-Ala-Phe) & 100 & 200 & - & - & {$[26]$} \\
\hline $\mathrm{Cu}(\mathrm{L}-\mathrm{Phe}-\mathrm{Ala})$ & 100 & 200 & - & - & {$[26]$} \\
\hline$[\mathrm{Cu}$ (bipy) $] \mathrm{Cl}_{2}$ & - & $60 \%{ }^{*}$ & - & - & {$[27]$} \\
\hline$[\mathrm{Cu}(\mathrm{dmb})] \mathrm{Cl}_{2}$ & - & $60 \%{ }^{*}$ & - & - & {$[27]$} \\
\hline$[\mathrm{Cu}($ phen $)] \mathrm{Cl}_{2}$ & - & $10 \%{ }^{*}$ & - & - & [27] \\
\hline$[\mathrm{Cu}(4$ met-phen $)] \mathrm{Cl}_{2}$ & - & $10 \%{ }^{*}$ & - & - & [27] \\
\hline$[\mathrm{Cu}($ neo $)] \mathrm{Cl}_{2}$ & - & $10 \%{ }^{*}$ & - & - & {$[27]$} \\
\hline$\left[\mathrm{Cu}\left(5-\mathrm{NO}_{2} \text {-phen }\right)_{2}\right] \mathrm{Cl}_{2}$ & - & 5.0 & 16 & - & [28] \\
\hline [Cu(gly-val)(phen)] & 1.0 & - & 15 & 14 & [29] \\
\hline [Cu(ala-gly)(phen)] & 1.0 & - & 7.5 & 9.5 & [29] \\
\hline$[\mathrm{Cu}($ ala-phe $)($ phen $)]$ & 0.94 & - & 2.0 & 1.0 & [29] \\
\hline$[\mathrm{Cu}($ phe-ala)(phen) $]$ & 13 & - & 7.0 & 9.90 & [29] \\
\hline$[\mathrm{Cu}($ phe-val)(phen)] & 7.4 & - & 3.1 & 7.1 & [29] \\
\hline$[\mathrm{Cu}($ phe-phe)(phen)] & 9.6 & - & 5.2 & 7.8 & [29] \\
\hline$\left[\mathrm{Cu}(\right.$ Ala-Phe $)\left(5-\mathrm{NO}_{2}\right.$-phen $\left.)\right]$ & - & 4.0 & 13 & - & {$[28]$} \\
\hline$\left[\mathrm{Cu}(\mathrm{Phe}-\mathrm{Ala})\left(5-\mathrm{NO}_{2}\right.\right.$-phen $\left.)\right]$ & - & 8.4 & $>20$ & - & {$[28]$} \\
\hline$\left[\mathrm{Cu}(\mathrm{Phe}-\mathrm{Val})\left(5-\mathrm{NO}_{2}\right.\right.$-phen $\left.)\right]$ & - & 4.8 & 14 & - & {$[28]$} \\
\hline$\left[\mathrm{Cu}(\mathrm{Phe}-\mathrm{Phe})\left(5-\mathrm{NO}_{2}\right.\right.$-phen $\left.)\right]$ & - & 9.3 & $>20$ & - & {$[28]$} \\
\hline$[\mathrm{Cu}(\mathrm{ida})(\mathrm{bam})]$ & - & $80 \%{ }^{*}$ & - & - & {$[27]$} \\
\hline [Cu(ida)(bipy)] & - & $70 \%{ }^{*}$ & - & - & {$[27]$} \\
\hline$[\mathrm{Cu}(\mathrm{ida})(\mathrm{dmb})]$ & - & $60 \%{ }^{*}$ & - & - & {$[27]$} \\
\hline [Cu(ida)(phen)] & - & $50 \%{ }^{*}$ & - & - & {$[27]$} \\
\hline [Cu(ida)(4met-phen)] & - & $30 \%{ }^{*}$ & - & - & {$[27]$} \\
\hline [Cu(ida)(neo)] & - & $10 \%{ }^{*}$ & - & - & {$[27]$} \\
\hline [Cu(ida)(batho)] & - & $10 \%{ }^{*}$ & - & - & {$[27]$} \\
\hline$\left[\mathrm{CuCl}(\mathrm{dmbpy})\left(\mathrm{PPh}_{3}\right)\right]$ & - & 8.4 & 4 & 4.5 & {$[30]$} \\
\hline$\left[\mathrm{CuCl}(\right.$ phen $\left.)\left(\mathrm{PPh}_{3}\right)\right] \cdot 0,25 \mathrm{H} 2 \mathrm{O}$ & - & 4.3 & 3.6 & 3.5 & {$[30]$} \\
\hline$\left[\mathrm{CuCl}(\right.$ neo $\left.)\left(\mathrm{PPh}_{3}\right)\right]$ & - & 1.4 & 2.8 & 1.3 & {$[30]$} \\
\hline Cisplatin & 50 & 50 & 30 & 50 & {$[28,30]$} \\
\hline
\end{tabular}

*Cytotoxic activity expressed as \% of cellular viability at $5 \mathrm{mM}$ of the complexes complexes coordinate to the DNA nucleobases, i.e. they form a covalent bond to the $\mathrm{N}$ of the bases, a mechanism similar to that of the Cisplatin. [Cu(L-Ala-Phe)] presented a $\mathrm{k}_{\mathrm{b}}$ of $1 \times 10^{4}[31]$.

Their cytotoxic activity is lower to that of the Cisplatin [26].

Homoleptic $[\mathrm{Cu}$ (diimine) $] \mathrm{Cl}_{2}$ present varied cytotoxic activity, higher than that of the Cisplatin.

\section{[Cu(L-dipeptide)(phen)] and $\left[\mathrm{Cu}(\mathrm{L}\right.$-dipeptide $)\left(5 \mathrm{NO}_{2}\right.$-phen $\left.)\right]$}

Trying to improve the activity of $\mathrm{Cu}$-L-dipeptide complexes, we introduced diimines as second ligands on the CuL-dipeptide complexes, preparing heteroleptic complexes (ie containing two different ligands).

Firstly, Cu-L-dipeptide-phen heteroleptic complexes were prepared. A general scheme of their molecular structure is presented in Figure 2.

The introduction of phen increased the lipophilicity of the complexes, which could improve cellular uptake. Phen works as an ancillary ligand making these complexes intercalate to DNA, as determined by UV-vis, EPR and DC methods.

$\mathrm{Cu}$-L-dipeptide-phen presented high cytotoxic activity, being all more active than Cisplatin (presenting a lower IC50) [29].

Heteroleptic $\mathrm{Cu}(\mathrm{II})$ complexes with $\mathrm{L}$-dipeptide and $5-\mathrm{NO}_{2}$-phen were studied to evaluate the influence of the $5-\mathrm{NO}_{2}$-phen moiety in their DNA binding and cytotoxic activity.

DNA binding studies shows that $5-\mathrm{NO}_{2}$-phen (and its complexes) binds to isolated DNA [28]. It also suggests an intercalative mode of binding of the 5- $\mathrm{NO}_{2}$-phen and its complexes to the DNA, as observed for other $\mathrm{Cu}-5-\mathrm{NO}_{2}$-phen heteroleptic complexes [32]. The stacking of the complex molecules possibly occurs through the 5- $\mathrm{NO}_{2}$-phen moiety, between the base pairs of DNA. These results are similar to those of the phen ligand and its complexes. The extent of the binding is lower, suggesting that the $5-\mathrm{NO}_{2}$ group impairs DNA binding, as determined by $\mathrm{CD}$ studies. A similar behavior was reported for $\mathrm{Ru}$ heteroleptic complexes [33].

All of the complexes present higher cytotoxic activity than Cisplatin. [Cu(dipeptide) $\left(5-\mathrm{NO}_{2}\right.$-phen)] complexes show similar activity to $\left[\mathrm{Cu}\left(5-\mathrm{NO}_{2}-\text { phen }\right)_{2}\right] \mathrm{Cl}_{2}$. [Cu(Ala-Phe $)\left(5-\mathrm{NO}_{2}-\right.$ phen $\left.)\right]$ is the more active. Compared with their phen analogs, the $5-\mathrm{NO}_{2}$-phen complexes present lower activity. This tendency was previously observed in the Casiopeinas series, where complexes containing 5- $\mathrm{NO}_{2}$-phen had larger IC50 than their counterparts with phen [34], showing the relevance of the phen moiety on the activity of the complexes.

This reduction of the cytotoxic activity is possibly related to the fact that the nitro group impairs DNA binding. The electron-attractor effect of the nitro substituent on the phen can also influence the reactivity of the $\mathrm{Cu}$ center in the complexes and therefore their activity.

\section{[Cu(ida)(diimine)] complexes}

A simpler ligand than dipepdides was assayed as coligand to neutralize the charge of the $\mathrm{Cu}$ (diimine) ${ }^{2+}$ core. Heteroleptic $\mathrm{Cu}$ (iminodiacetate) (diimine)] complexes were prepared with a variety of diimines to study their influence in the DNA binding and cytotoxic activity. A general scheme of their molecular structure is presented in Figure 3.

DNA binding results show that all the complexes bind to the DNA, but induce different changes as studied by $\mathrm{CD}$. Complexes [Cu(ida) (bam) $\left.\left(\mathrm{H}_{2} \mathrm{O}\right)\right],[\mathrm{Cu}(\mathrm{ida})($ bipy) $]$ and $[\mathrm{Cu}(\mathrm{ida})($ neo) $]$ bind by partial intercalation to the DNA. Complex $\left[\mathrm{Cu}(\mathrm{ida})\left(5 \mathrm{NO}_{2}-\right.\right.$ phen $\left.)\left(\mathrm{H}_{2} \mathrm{O}\right)\right]$ 
<smiles>c1ccc(Nc2ccccn2)nc1</smiles>

2,2'-dipyridil-amine (bam)

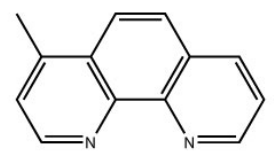

4-methyl-1,10-phenanthroline 5-nitro-1,10-phenanthroline (4met-phen)

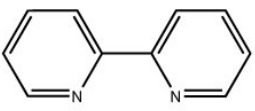

2,2'-bipyridine (bipy)

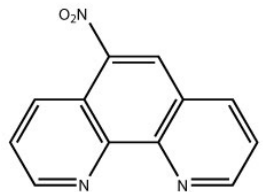

(5nitro-phen)
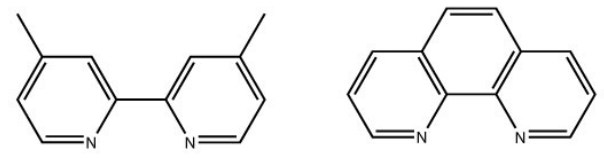

1,10-phenanthroline (phen)

4,4'-dimethyl-2,2'-bipyridine dmb)

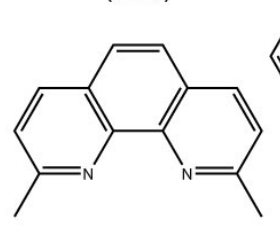

neocuproine (neo)
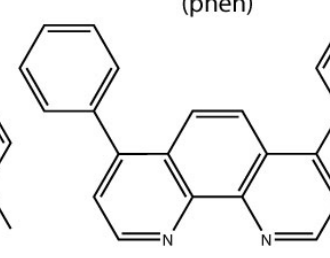

bathophenanthroline (batho)

Figure 1. Schematic representation and abbreviation of the different diimines used in this work

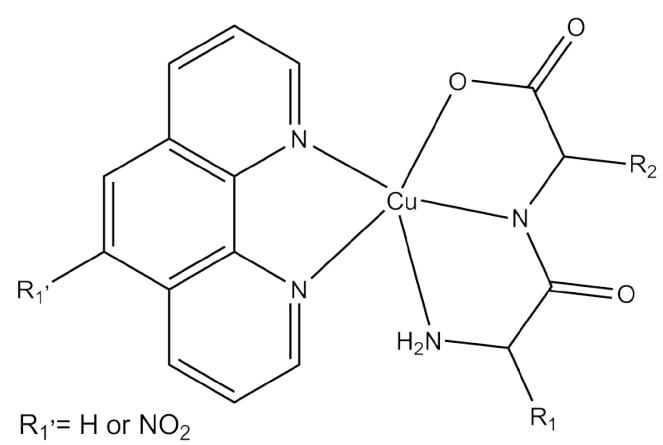

Figure 2. Schematic representation of the molecular structure of the $[\mathrm{Cu}(\mathrm{L}-$ dipeptide $)$ (phen)] and $\left[\mathrm{Cu}\right.$ (L-dipeptide) $\left(5-\mathrm{NO}_{2}\right.$-phen) $)$ complexes

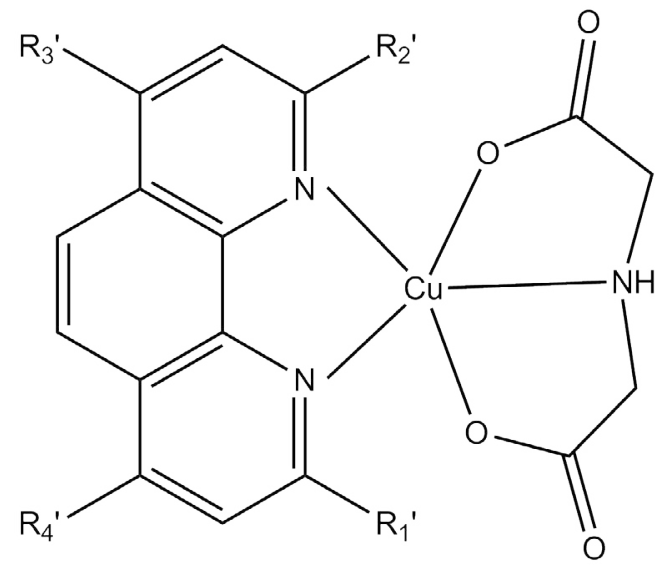

Figure 3. Schematic representation of the molecular structure of the $[\mathrm{Cu}(\mathrm{ida})(\mathrm{diimine})$ complexes

induce $\mathrm{B}$ to $\mathrm{C}$ conformational change on DNA. Complexes [Cu(ida) (phen) $\left.\left(\mathrm{H}_{2} \mathrm{O}\right)\right]$ and $[\mathrm{Cu}(\mathrm{ida})(4$ methyl-phen)] induce $\mathrm{B}$ to $\mathrm{A}$ form conformational change on DNA. Complex [Cu(ida)(batho)] induces conformational change from the right-handed $\mathrm{B}$ to the left-handed $\mathrm{Z}$ form of the DNA. Their $\mathrm{Kb}$ are in the range 1-3 $\times 10^{3}$.

As complexes with $\mathrm{IC}_{50}$ in the lower micromolar range has been considered to show significant cytotoxic activity [7], for these complexes the activity was determined at a fixed dose of $5 \mu \mathrm{M}$.

All complexes show increased cytotoxicity than Cisplatin, as observed in Table 1. Among the studied complexes [ $\mathrm{Cu}(\mathrm{ida})($ neo)] and $[\mathrm{Cu}(\mathrm{ida})(\mathrm{batho})]$ present the higher activity, comparable to those presented by other complexes catalogued as promising antitumor agents [25,35-37]. No correlation can be stated between the cytotoxic activity and DNA binding ( $K_{\mathrm{b}}$ or induced conformational changes). $\mathrm{Cu}(\mathrm{ida})(4$ met-phen) $], \quad[\mathrm{Cu}(\mathrm{ida})($ phen $)]$ and $[\mathrm{Cu}($ ida)(batho) $]$ complexes present significant cytotoxic activity. The order of activity is in agreement with results observed in other series of $\mathrm{Cu}$-diimine mixed ligand complexes [34].

In other series of $\mathrm{Cu}(\mathrm{II})$ mixed ligand complexes containing diimines, a similar relation between the aromatic di-imine ligand and the cytotoxic activity was observed [34].

The cytotoxic activity of the heteroleptic complexes is similar to that of the corresponding homoleptic $\left[\mathrm{Cu}\right.$ (diimine) $\left.\mathrm{Cl}_{2}\right]$ complex. It suggests that in vivo the complexes are dissociated to the respective $[\mathrm{Cu}$ (diimine)] complex. This is in agreement with the expected reduction of $\mathrm{Cu}$ (II) to $\mathrm{Cu}(\mathrm{I})$ inside the cell, which favors the release of the ida ligand. Therefore, the active species could be the cationic ones.

\section{Copper (I) complexes of diimines}

Intracellular copper is in the chemical form of $\mathrm{Cu}(\mathrm{I}) ; \mathrm{Cu}(\mathrm{II})$ complexes are believed to be reduced to $\mathrm{Cu}(\mathrm{I})$ in the intracellular media $[7,24,38]$. Despite that, few studies report on the antitumor activity of $\mathrm{Cu}(\mathrm{I})$ complexes, probably due to the difficulty in obtaining stable $\mathrm{Cu}(\mathrm{I})$ complexes in aqueous media. Encouraged by the activity and low toxicity of HydroCuP we explored the cytotoxic activity of $\mathrm{Cu}$-diimine systems adding phosphine ligands to stabilize $\mathrm{Cu}(\mathrm{I})$. A general scheme of their molecular structure is presented in Figure 4.

The complexes degrade DNA rapidly therefore no binding constant could be determined.

All the complexes present higher cytotoxic activity than Cisplatin and according to Santini et al. [7] may be classified as very active (IC50 in the low micromolar range). The cytotoxic activity increases in the same order as observed for the lipophilicity, being $\left[\mathrm{Cu}(\mathrm{neo})\left(\mathrm{PPh}_{3}\right) \mathrm{Cl}\right]$ the most lipophilic and active. This observation is in agreement with the hypothesis that the complexes act as "copper ionophores" that deliver copper inside the cell $[39,40]$.

\section{Proposed mechanism of action of the complexes}

As mentioned in Section 1, the mechanisms underlying the biological activity of $\mathrm{Cu}$-complexes are not completely known $[14,15]$. 


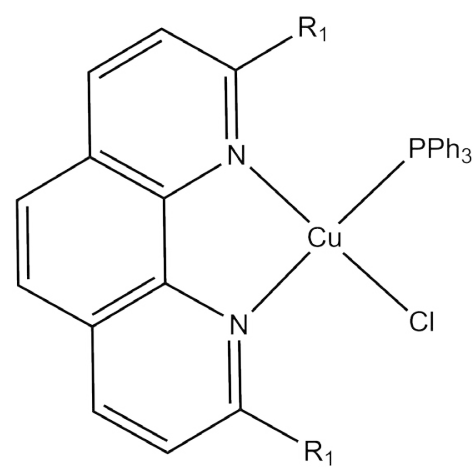

$$
\mathrm{R}_{1}=\mathrm{H} \text { (phen), } \mathrm{CH}_{3} \text { (neo) }
$$

Figure 4. Schematic representation of the molecular structure of the $[\mathrm{Cu}($ diimine)(phosfine) Cl] complexes

Taken our results into account and the literature it can be proposed that the molecular events that cause the cytotoxic activity of $\mathrm{Cu}$ diimine complexes include:

- Intercalation to the DNA inducing different conformational changes or even DNA degradation. Only Cu-L-dipeptide complexes coordinate to DNA as Cisplatin.

- Generation of ROS which oxidize and degrade biomolecules, as DNA [41]. ROS production in vitro has been observed for related complexes.

- Mitochondrial toxicity as observed in the literature for related $\mathrm{Cu}$ complexes [42].

In the case of the $[\mathrm{Cu}(\mathrm{ida})(\mathrm{batho})]$ complex, the more lipophilic one, it is possible that the activity is due to the formation of a lipophilic delocalized cation $[\mathrm{Cu} \text { (batho) }]^{2+}$, which are known to selectively accumulate in mitochondria of cancer cells $[43,44]$. These effect can't be ruled out for the rest of the compounds, that is, the active species for these complexes can be the cation (more or less lipofilic) $[\mathrm{Cu} \text { (diimine) }]^{2+}$.

With relation to the cellular death mechanism, for related copper complexes cellular death by an apoptotic mechanism was observed $[7,42]$. Despite that, cellular death by a parapoptotic mechanism can't be ruled out as it was reported for Cu-phosphine complexes [12,39].

\section{Conclusions and perspectives}

All complexes bind to DNA, being the diimine the ligand which most influenced the DNA binding. All the complexes were active against the tested tumor cell lines, most of them with increased activity than the reference drug Cisplatin. The diimine plays a central role in the anticancer activity, possible being the $[\mathrm{Cu} \text { (diimine) }]^{+}$the active species inside the cell. The anionic ligand modulates the activity. There is no apparent relationship between DNA binding and cytotoxic activity.

Among all the dipeptide containg complexes, those containg L-Ala-Phe are the more actives, although the dipeptide itself doesn't present cytotoxic activity. This fact is probably related to the major stability of the complex. [Cu(ala-phe)(phen)], $\left[\mathrm{CuCl}(\right.$ neo $\left.)\left(\mathrm{PPh}_{3}\right)\right]$, [Cu(ida)(neo)], [Cu(ida)(batho)] and $[\mathrm{Cu}(\mathrm{ida})(4$ met-phen) $]$ showed the strongest cytotoxic activity against cancer cell lines and therefore, those compounds are good candidates to test its antitumor activity in vivo.

More research is needed in order to establish structure - activity relationship and advance towards the rational design of Copperdiimine complexes with antitumor activity.
In vivo studies are necessary to advance in the potential use of these compounds as metallo drugs, especially to gain insight in their selectivity and eventual cure rates which are not accessible by in vitro assays.

\section{Acknowledgements}

The authors thank PEDECIBA, ANII and CSIC (Uruguay); CAPES (grant grant 050/13) and $\mathrm{CNPq}$ (Brazil) for financial support.

\section{References}

1. Rosenberg B, VanCamp L, Trosko JE, Mansour VH (1969) Platinum compounds: a new class of potent antitumour agents. Nature 222: 385-386. [Crossref]

2. Johnstone TC, Suntharalingam K, Lippard SJ (2016) The next generation of platinum drugs: targeted Pt (II) agents, nanoparticle delivery, and Pt (IV) prodrugs. Chem Rev 116: 3436-3486. [Crossref]

3. Rijt SHv, Sadler PJ (2009) Current applications and future potential for bioinorganic chemistry in the development of anticancer drugs. Drug Discov Today 14: 1089-1097. [Crossref]

4. Jakupec MA, Galanski M, Arion VB, Hartinger CG, Keppler BK (2008) Antitumour metal compounds: more than theme and variations. Dalton Trans 14: 183-194. [Crossref]

5. Yang M, Bierbach U (2017) Metal-Containing Pharmacophores in Molecularly Targeted Anticancer Therapies and Diagnostics. Eur J Inorg Chem 12: 1561-1572.

6. Alessio E, Guo Z (2017) Metal Anticancer Complexes-Activity, Mechanism of Action, Future Perspectives. Eur J Inorg Chem 12: 1539-1540.

7. Santini C, Pellei M, Gandin V, Porchia M, Tisato F, et al. (2014) Advances in copper complexes as anticancer agents. Chem Rev 114: 815-862. [Crossref]

8. McGivern T, Afsharpour S, Marmion C (2017) Copper Complexes as Artificial DNA Metallonucleases: From Sigman's Reagent to Next Generation Anti-Cancer Agent? Inorganica Chimica Acta.

9. Mahalakshmi R, Raman N (2016) A therapeutic journey of mixed ligand complexes containing 1,10-phenanthroline derivatives: a review. Chemistry 16: 18.

10. Serment-Guerrero J, Cano-Sanchez P, Reyes-Perez E, Velazquez-Garcia F, BravoGomez ME, et al. (2011) Genotoxicity of the copper antineoplastic coordination complexes casiopeinas ${ }^{\circledR}$. Toxicology In Vitro 25: 1376-1384. [Crossref]

11. Davila-Manzanilla SG, Figueroa-de-Paz Y, Mejia C, Ruiz-Azuara L (2017) Synergistic effects between a copper-based metal Casiopeína III-ia and cisplatin. Eur J Med Chem 129: 266-274. [Crossref]

12. Gandin V, Pellei M, Tisato F, Porchia M, Santini C, et al. (2012) A novel copper complex induces paraptosis in colon cancer cells via the activation of ER stress signalling. J Cell Mol Med 16: 142-151. [Crossref]

13. Gandin V, Ceresa C, Esposito G, Indraccolo S, Porchia M, et al. (2017) Therapeutic potential of the phosphino $\mathrm{Cu}(\mathrm{I})$ complex (HydroCuP) in the treatment of solid tumors. Sci Rep 7: 13936. [Crossref]

14. Campero-Peredo C, Bravo-Gómez ME, Hernández-Ojeda SL, Olguin-Reyes Sdel R, Espinosa-Aguirre JJ, et al. (2016) Effect of [Cu (4, 7-dimethyl-1, 10-phenanthroline) (acetylacetonato)] NO 3, Casiopeína III-Ea, on the activity of cytochrome P450. Toxicol In Vitro 33: 16-22. [Crossref]

15. Gandin V, Trenti A, Porchia M, Tisato F, Giorgetti M, et al. (2015) Homoleptic phosphino copper (i) complexes with in vitro and in vivo dual cytotoxic and antiangiogenic activity. Metallomics 7: 1497-1507.

16. Nicco C, Laurent A, Chereau C, Weill B, Batteux F (2005) Differential modulation of normal and tumor cell proliferation by reactive oxygen species. Biomed Pharmacother 59: 169-174. [Crossref]

17. Tardito S, Bassanetti I, Bignardi C, Elviri L, Tegoni M, et al. (2011) Copper binding agents acting as copper ionophores lead to caspase inhibition and paraptotic cell death in human cancer cells. J Am Chem Soc 133: 6235-6242. [Crossref]

18. Gaál A, Mihucz VG, Bösze S, Szabó I, Baranyi M, et al. (2018) Comparative in vitro investigation of anticancer copper chelating agents. Microchem J 136: 227-235.

19. Alemón-Medina R, Breña-Valle M, Muñoz-Sánchez JL, Gracia-Mora MI, RuizAzuara L (2007) Induction of oxidative damage by copper-based antineoplastic drugs (Casiopeínas). Cancer Chemother Pharmacol 60: 219-228. 
20. Veal JM, Rill RL (1988) Sequence specificity of DNA cleavage by bis (1,10-phenanthroline)copper(I). Biochemistry 27: 1822-1827. [Crossref]

21. Alvarez N, Facchin G, Torre M (2011) Antioxidant and pro-oxidant properties and antiproliferative activity of homoleptic and heteroleptic copper complexes, potential antitumoral species. Metal Ions in Biology and Medicine.

22. Thomas AM, Nethaji M, Mahadevan S, Chakravarty AR (2003) Synthesis, crystal structure, and nuclease activity of planar mono-heterocyclic base copper (II) complexes. J Inorg Biochem 94: 171-178.

23. Ni Y, Lin D, Kokot S (2006) Synchronous fluorescence, UV-visible spectrophotometric, and voltammetric studies of the competitive interaction of bis (1,10-phenanthroline) copper (II) complex and neutral red with DNA. Anal Biochem 352: 231-242. [Crossref]

24. Tisato F, Marzano C, Porchia M, Pellei M, Santini C (2010) Copper in Diseases and Treatments, and Copper-Based Anticancer Strategies. Med Res Rev 30: 708-749. [Crossref]

25. Marzano C, Pellei M, Tisato F, Santini C (2009) Copper complexes as anticancer agents. Anticancer Agents Med Chem 9: 185-211. [Crossref]

26. Facchin G, Veiga N, Kramer MG, Batista AA, Várnagy K, et al. (2016) Experimental and theoretical studies of copper complexes with isomeric dipeptides as novel candidates against breast cancer. J Inorg Biochem 162: 52-61.

27. Alvarez N, Mendes LFS, GabrielaKramer M, Torre MH, Costa-Filho AJ, et al. (2018) Development of Copper (II)-diimine-iminodiacetate mixed ligand complexes as potential antitumor agents. Inorganica Chimica Acta.

28. Iglesias S, Alvarez N, Kramer MG, Torre MH, Kremer E, et al. (2015) Structural Characterization and Cytotoxic Activity of Heteroleptic Copper (II) Complexes with L-Dipeptides and 5-NO2-Phenanthroline. Crystal Structure of [Cu (Phe-Ala)(5-NO2Phen)]. 4H2O. Struct Chem Crystallogr Commun.

29. Iglesias S, Alvarez N, Kramer MG, Torre MH, Kremer E, et al. (2013) Towards the development of new copper compounds for the treatment of cancer: Study of the cytotoxic activity of $\mathrm{Cu}(\mathrm{L}$-dipeptide)(1,10-phenanthroline) complexes. Proceedings 12th International Symposium of Metal Ions in Biology and Medicine.

30. Alvarez N, Noble C, Torre MH, Kremer E, Ellena J, et al. (2017) Synthesis, structura characterization and cytotoxic activity against tumor cells of heteroleptic copper (I) complexes with aromatic diimines and phosphines. Inorganica Chimica Acta 466: 559-564.

31. Facchin G, Kremer E, Barrio DA, Etcheverry SB, Costa-Filho AJ, et al. (2009) Interaction of $\mathrm{Cu}$-dipeptide complexes with Calf Thymus DNA and antiproliferative activity of [Cu (ala-phe)] in osteosarcoma-derived cells. Polyhedron 28: 2329-2334.

32. Li XW, Li X, Li YT, Wu ZY, Yan CW (2012) Synthesis and structures of binuclear copper (II) complexes bridged by N-(5-chloro-2-hydroxyphenyl)- $\mathrm{N}^{\prime}$-[3(dimethylamino) propyl] oxalamide ligand: DNA-binding properties and cytotoxic activities. Journal of Organometallic Chemistry 700: 48-57.
33. Pyle A, Meshoyerer R, Kumar CV, Barton JK (1989) Mixed-ligand complexes of ruthenium (II): factors governing binding to DNA. J Am Chem Soc 111: 3051-3058.

34. Bravo-Gómez ME, Dávila-Manzanilla S, Flood-Garibay J, Muciño-Hernández MÁ, Mendoza Á, et al. (2012) Secondary Ligand Effects on the Cytotoxicity of Several Casiopeína's Group II Compounds. J Mex Chem Soc 56: 85-92.

35. Bravo-Gómez ME, García-Ramos JC, Gracia-Mora I, Ruiz-Azuara L (2009) Antiproliferative activity and QSAR study of copper (II) mixed chelate [Cu $(\mathrm{N}-\mathrm{N})$ (acetylacetonato) $] \mathrm{NO}<\mathrm{sub}>3$ and $[\mathrm{Cu}(\mathrm{N}-\mathrm{N})($ glycinato $)] \mathrm{NO}<\mathrm{sub}>3$ complexes,(Casiopeínas $<$ sup $>$ ( ). J Inorg Biochem 103: 299-309. [Crossref]

36. Rajalakshmi S, Weyhermüller T, Dinesh M, Nair BU (2012) Copper (II) complexes of terpyridine derivatives: A footstep towards development of antiproliferative agent for breast cancer. J Inorg Biochem 117: 48-59. [Crossref]

37. Patitungkho S, Adsule S, Dandawate P, Padhye S, Ahmad A, et al. (2011) Synthesis, characterization and anti-tumor activity of moxifloxacin-Copper complexes against breast cancer cell lines. Bioorg Med Chem Lett 21: 1802-1806. [Crossref]

38. Iakovidis I, Delimaris I, Piperakis SM (2011) Copper and Its Complexes in Medicine: A Biochemical Approach. Mol Biol Int

39. Marzano C, Gandin V, Pellei M, Colavito D, Papini G, et al. (2008) In vitro antitumor activity of the water-soluble copper (I) complexes bearing the tris (hydroxymethyl) phosphine ligand. J Med Chem 51: 798-808. [Crossref]

40. Tisato F, Marzano C, Peruzzo V, Tegoni M, Giorgetti M, et al. (2016) Insights into the cytotoxic activity of the phosphane copper(I) complex [Cu(thp)4][PF6]. $J$ Inorg Biochem 165: 80-91. [Crossref]

41. Serment-Guerrero J, Bravo-Gomez ME, Lara-Rivera E, Ruiz-Azuara L (2017) Genotoxic assessment of the copper chelated compounds Casiopeinas: Clues about their mechanisms of action. J Inorg Biochem 166: 68-75. [Crossref]

42. García-Ramos JC, Gutiérrez AG, Vázquez-Aguirre A, Toledano-Magaña Y, AlonsoSáenz AL, et al. (2016) The mitochondrial apoptotic pathway is induced by $\mathrm{Cu}$ (II) antineoplastic compounds (Casiopeínas $\left.{ }^{\circledR}\right)$ in SK-N-SH neuroblastoma cells after short exposure times. BioMetals 30: 43-58. [Crossref]

43. Filomeni G, Piccirillo S, Graziani I, Cardaci S, Da Costa Ferreira AM, et al. (2009) The isatin-Schiff base copper (II) complex $\mathrm{Cu}$ (isaepy) 2 acts as delocalized lipophilic cation, yields widespread mitochondrial oxidative damage and induces AMP-activated protein kinase-dependent apoptosis. Carcinogenesis 30: 1115-1124. [Crossref]

44. Modica-Napolitano JS, Aprille JR (2001) Delocalized lipophilic cations selectively target the mitochondria of carcinoma cells. Adv Drug Deliv Rev 49: 63-70. [Crossref]

Copyright: (2018 Alvarez N. This is an open-access article distributed under the terms of the Creative Commons Attribution License, which permits unrestricted use, distribution, and reproduction in any medium, provided the original author and source are credited. 